\title{
The Space and Liminality of Folding Screens: Iconography of the Sea and Pine Trees
}

\author{
IDo Misato
}

\author{
Translated by Kristopher REEVES
}

\section{Introduction: Unfolding a Folding Screen}

Folding screens, as their Sinitic name, byōbu 厥風, implies, serve to block out (byo) undesired drafts $(b u)$. Furthermore, these screens serve as practical portable partitions for separating larger spaces into smaller compartments. Historical documents strongly suggest that, aside from these more obviously pragmatic functions, folding screens were also employed for ceremonial purposes in various annual events and other ritual spaces. Unlike more permanent partitions, such as sliding doors decorated with painted images (fusuma 襖), folding screens could be stored away, taken out, and moved about as necessity required. Consequently, it is often difficult to say with much precision exactly where a given folding screen might once have been used. Moreover, while documents from the Heian period include numerous references to folding screens, evidence that such furnishings were indeed abundant, only one folding screen from the period has survived to the present, namely, the byōbu depicting a landscape scene (Senzui byöbu 山水屏風) preserved at Tōji Temple 東寺. With such a dearth of extant examples, it is no easy task to reconstruct the world of artistic imagery once seen on folding screens throughout the Heian period.

Comprehensive research into those spaces in which folding screens were employed has already been carried out. Investigations of so-called "paintingswithin-paintings" (gachüga 画中画), depictions of painted folding screens embedded within illustrations found in illustrated scrolls (emaki 絵巻), have revealed a great deal about such spaces. ${ }^{1}$ For example, in the Hönen Shönin eden 法然上人絵

\footnotetext{
${ }^{1}$ See Mochimaru Kazuo 持丸一夫, “Ishiyamadera engi to Boki ekotoba ni arawareta shōheiga” 石 山寺縁起と慕記絵詞に現れた障屏画，Bijutsu kenkyn̄，169，March 1953. Mochimaru Kazuo “Hōnen eden ni arawareta shōheiga” 法然絵伝に現れた障屏画, Bijutsu kenkyū, 171, November 1953. Takeda Tsuneo 武田恒夫, “Chūsei shōheiga to sono gachūga” 中世障屏画とその画中画, in Chüsei shōheiga 中世障屏画. Kyoto: Kyōto National Museum, 1970.
} 
伝 (Illustrated Biography of Master Hōnen, 1307-1310) we find a depiction of Hōnen's (1133-1212) birth (scroll 1, section 2), as well as another of the death of his father, who died around the year 1141 (scroll 1, section 5). Likewise, in the Takada Manuscript of Shinran shōnin eden 親鸞聖人絵伝 (Illustrated Biography of Master Shinran, oldest manuscript dated 1295), we find depictions of Shinran's (1173-1263) taking the tonsure, as well as his funeral. All of these scenesdepictions of birth, departure from the home to become a monk, and deathinclude illustrations of folding screens. Scroll 1, section 3 of the Taima mandara engi emaki 当麻曼茶羅縁起絵巻 (Illustrated Scroll of the Origins of the Taima Mandara, mid-Kamakura) includes an illustration of Princess Chūjō 中将姫 (747-775) and a Buddhist nun dipping lotus fibers into a well in order to prepare the thread for dying - thread which, bound as it is to be used in weaving the Taima mandara, suddenly and miraculously takes on five vibrant colors. In this scene, the princess and her female companions are surrounded by a series of folding screens. Scroll 5, section 1 of the Ishiyamadera engi emaki 石山寺縁起絵巻 (Illustrated Scroll of the Origin of Ishiyamadera Temple, mid-fourteenth century) shows the estranged wife of Fujiwara no Kuniyoshi 藤原国能 (n.d.) secluding herself within the precincts of Ishiyamadera Temple, vowing to remain within the temple until her death. Behind her stands a folding screen, in front of which can be seen the bodhisattva Kannon, appearing in her dream in response to the woman's prayers.

These and other examples of the sort draw attention to the fact that folding screens, beyond their more mundane, purely practical function as indoor furnishings, furthermore served as a material medium capable of delineating temporary spaces. Kanmon nikki 看聞日記 (Memoir of Things Seen and Heard, 1416-1448), a diary composed by Prince Sadafusa 貞成親王 (1372-1456), father of Emperor Go-Hanazono 後花園天皇 (1419-1471, r. 1428-1464), and which records details of daily court life and rituals, demonstrates that folding screens were an integral part of the indoor furnishings prepared especially for such auspicious occasions as Buddhist services, poetry matches, and tea ceremonies. Interestingly, folding screens, which were prepared (or sometimes borrowed) prior to the event in which they were to be used, were promptly removed and stored away, along with the flowers and vases, soon after the event in question had been concluded. That is to say, folding screens were erected not merely as decorative accoutrements, but as partitions delineating a sacred ceremonial space, clearly separating that space from the mundane world. ${ }^{2}$ An illustration appearing in Daijoin jisha rojiiki 大乗院 寺社雑事記 (Miscellaneous Records of Daijoin Temple, 1450-1527) depicts the scene at a Tanabata 七夕 Festival, in which the sitting area is surrounded by a gold-leaf-gilt folding screens (see Figure 1).

\footnotetext{
${ }^{2}$ Ido Misato 井戸美里, “Kanmon nikki ni okeru zashiki no shitsurai” 看聞日記における座敷の 室礼, in Matsuoka Shinpei 松岡心平, ed., Kanmon nikeki to chüsei bunka 看聞日記と中世文化. Tokyo: Shinwasha, 2010.
} 
This article is an investigation into the function of folding screens, during the fifteenth and sixteenth centuries, as temporary delineators of sacred spaces, with special emphasis on the materiality and iconography of these screens. I will consider here only those folding screens decorated with paintings dealing primarily with what are conventionally considered native Japanese themes-collectively known as yamato-e byöbuやまと絵娓風, or Yamato-style painted folding screensas opposed to those screens decorated with images reminiscent of Sinitic themes and personages (kara-e byöbu 唐絵娓風).

\section{Yamato-style Folding Screens: Materiality and Function as Delineators of Sacred Space}

An entry in the aforementioned Kanmon nikki dated to the sixth day of the seventh month in the fourth year of Eikyō 永享 (1432) gives some details about those furnishings prepared for the Tanabata Festival that was to take place the following evening. In particular, two folding screens were borrowed expressly for the occasion: one, which depicted pine trees in four seasons, was accentuated with some form of gold pigment or foil (kinmigakitsuke 金磨付), while other sported paintings of the sea, boats, and pine trees. This entry, being one of the earliest records of Yamato-style folding screens from the Muromachi period, has drawn much attention. Unfortunately, very few actual examples of folding screens from that period survive. Furthermore, as the Muromachi period saw the efflorescence of a new style of ink painting deeply influenced by Zen philosophy, not much consideration has been given to painted folding screens of that era. An exhibition entitled "Folding Screens of the Muromachi Period" (Muromachi jidai no byōbu-e), held at the Tokyo National Museum back in 1989, which introduced the public to then newly discovered folding screens, marked the first attempt at drawing attention to this topic. The catalogue published in association with this exhibition contains an introductory essay by Tsuji Nobuo 辻惟雄, a specialist in the history of Japanese art, which is especially informative. Somewhat more recently, in 2007, the Suntory Museum of Art organized an exhibition entitled "BIOMBO/byöbu," in which the function of folding screens received serious consideration. ${ }^{3}$ In this section, using the entry from Kanmon nikeki mentioned above as a starting point, I would like to consider in some detail the materiality of gold pigment or foil, as well as iconography of the sea, boats, and pines.

I will begin with a brief summary of extant Yamato-style folding screens produced duringt the fifteenth and sixteenth centuries. Four such examples, insofar as

\footnotetext{
${ }^{3}$ Sakakibara Satoru 榊原悟, “Byōbu=girei no ba no chōdo: sōsō to shussan wo rei ni" 屏風= 儀礼の場の調度一葬送と出産を例に, in Nagaoka Ryūsaku 長岡龍作, ed., Köza Nihon bijutsushi daiyonkan zōkei no ba 講座日本美術史 第四巻 造形の場, Tokyo: Tōkyō Daigaku Shuppankai, 2005. Considerations in this article pertaining to the function of folding screens in relation to funerals and childbirth rely to a great deal on Sakakibara's research.
} 
they seem to reflect the sort of paintings recorded in Kanmon nikki, are particularly noteworthy here: the "Matsuzu byōbu" 松図屏風 (Pine Screen), attributed to Tosa Mitsunobu 土佐光信 (c.1434-1525) (Tokyo National Museum); three folding screens known collectively as “Hamamatsuzu byōbu” 浜松図屏風, depicting pine trees growing along the seashore, one of which is privately owned, the other two being in the collections of Tokyo National Museum and the Agency for Cultural Affairs; the “Jitsugetsu sansuizu byōbu" 日月山水図屏風, containing paintings of the sun, moon, and landscape (Kongōji Temple 金剛寺, Osaka); and the "Shiki kabokuzu byōbu" 四季花木図屏風, which depicts seasonal flowers (Idemitsu Museum of Arts). Izumi Mari avers that these folding screens were intended to serve as decorative furnishings for auspicious events, considering the generous use of gold, silver, and mica, embellishments often found on decorative offertory sutras. ${ }^{4}$

Next, let us return to contemporaneous written records and see in what manner these decorative folding screens were used. The first folding screen mentioned in the entry from Kanmon nikki — pine tree in all four seasons, embellished with gold pigment or foil- is the first recorded instance of a gold-ground folding screen decorated with the image of a pine tree. Entries regarding Buddhist services conducted for the shogun found in the diary Inryoken nichiroku 院凉軒日 録 (Daily Records of the Inryöken, 1435-1493) reveals that on such occasions, folding screens depicting pine trees surrounded by azaleas, bamboo were erected behind memorial tablets and household altars (see entries for Chōkyō 長享 3 [1489]4.8 and Entoku 延徳 3 [1491]1.28). We are told, in this same source, that it sometimes took up to several months before gold-ground folding screens of this sort could be obtained for a funeral. The presence of such lavish furnishings at funerals was an absolute necessity. Moreover, aside from their use within Japanese households, Yamato-style folding screens embellished with gold pigment or foil were also sent as gifts to China and Korea. ${ }^{5}$ Documents from the fifteenth and sixteenth centuries bear ample witness to the fact that these gold-ground folding screens were produced and employed exclusively for special events and ceremonies. A number of theories have been put forward as to the precise nature of the term kinmigakitsuke - gold pigment or foil. It would appear that this method of embellishing folding screens was somewhat different from that used in later generations, namely, the application of minute gold flakes or foil over the entire surface of the folding screen. Instead, this older method consisted of a layer of adhesive gold pigment (kindei 金泥)—a mixture of gold foil and glue-spread over the surface of the screen, to which was then variously applied

\footnotetext{
${ }^{4}$ Izumi Mari 泉万里, “Chūsei byōbu no kira to kingin” 中世屏風の雲母と金銀, Kokka, 117, August 1995.

${ }^{5}$ Akazawa Eiji 赤澤英二, “Jūgo seiki ni okeru kinbyōbu ni tsuite”十五世紀に抢ける金屏風に ついて, in Takeda Tsuneo 武田恒夫 and Yamane Yūzō 山根有三, ed., Nihon byōbue shüsei 日本屏 風絵集成, volume 6. Tokyo: Kōdansha, 1978.
} 
finely cut filaments and powder-like flecks of gold foil, known respectively as noge 野毛 (wild hair) and sunago 砂子 (sand grain). ${ }^{6}$

It is not surprising that gold-ground folding screens should have been associated with Buddhist services, considering the many depictions in Buddhist scriptures of the Pure Land, a paradise whose ponds and roads purportedly shimmered with a bright golden hue. Furthermore, Takeda Tsuneo has pointed out that the highly refined and finished quality, the very materiality of gold foil itself, might have readily suggested itself to contemporary minds as something befitting religious events. ${ }^{7}$ Rooms designated for the purpose of childbirth were decorated not with gold-ground folding screens, but with screens embellished exclusively with mica (shiroe byōbu 白絵屏風), giving them a distinctly whitish glow. Mica was believed to exert salubrious medicinal effects. ${ }^{8}$ Yamato-style folding screens embellished with various combinations of gold, silver, and mica were clearly differentiated: a preponderance of gold foil destined one screen for Buddhist services, while a preponderance of mica made another suitable for the precarious ordeal of childbirth. Whatever the occasion, these folding screens served as partitions marking off a sacred or pure space from the more secular, surrounding areas. It was, in fact, the glistening qualities of gold, silver, and mica pigment-the concrete materiality of these substances-that endowed these folding screens with the perceived power to transform secular and impure space into sacred purified space. Of course, the materiality of these screens was not the only factor at play. The specific images and motifs painted upon their surfaces contributed just as much to the elevated status of folding screens and their use in special occasions. One clear example of this is the presence on mica-ground folding screens erected during childbirth of such auspicious images as pine trees, bamboo, cranes, and turtles, all of which suggest longevity and constancy. The aforementioned "Senzui byōbu" and "Jitsugetsu sansuizu byōbu" (Kongōji Temple) are said to have been used during Esoteric initiation rituals (kanjō灌頂) for Buddhist monks. We may safely conclude that natural images of mountains, rivers, the sun, and the moon, as depicted on these and other similar screens, were seen as fitting images for these ceremonies.

\section{Iconography of Yamato-style Folding Screens}

The three "Hamamatsuzu byōbu" mentioned above are, representative examples of folding screens produced during the fifteenth and sixteenth centuries, each depicting pine trees growing along the seashore, along with the occasional

\footnotetext{
${ }^{6}$ Yamane Yūzō, "Muromachi jidai kaiga ni okeru kin to gin: senmenga to byōbue wo chūshin ni” 室町時代絵画における金と銀一扇面画と屏風絵を中心に一, Kokka, 1200, November 1995.

${ }^{7}$ Takeda Tsuneo 武田恒夫, “Kinpeki shōhekiga ni tsuite” 金碧障壁画について, Bukkeyō geijutsu, 59, December 1965.

${ }^{8}$ Izumi Mari 泉万里, “Chūsei byōbu no kira to kingin” 中世屏風の雲母と金銀, Kokka, 117, August 1995.
} 
seasonal bird or flower (see Figure 2). ${ }^{9}$ These folding screens bring to mind the description of the second of two folding screens recorded in the entry in Kanmon nikki mentioned above. The diary describes this screen as having been decorated with images of the sea, boats, and pine trees. Among the three extant "Hamamatsuzu byōbu," there are those that, aside from seashore pines, also depict flowers and birds of the four seasons, along with small boats. Moreover, in the case of the aforementioned "Shiki kabokuzu byōbu" and "Jitsugetsu sansuizu byōbu", we see flowers of all four seasons lining the seashore. In the Ishiyamadera engi emaki, already introduced above in relation to the practice of embedding images of painted folding screens within paintings appearing in illustrated handscrolls, when the bodhisattva Kannon appears, we are shown a folding screen upon which can clearly be seen the image of a seashore pine, exactly of the type preserved in the "Hamamatsuzu byōbu" screens. Similarly, in the third section of an illustrated manuscript of the tale Utatane sōshiうたたね草子 ( $A$ Wakeful Sleep, early sixteenth century) (National Museum of Japanese History), we see a folding screen that depicts a seaside pine. This folding screen appears at a key moment in the tale when a woman, making her way to Ishiyamadera Temple - the same temple whose miraculous origins are recounted in the Ishiyamadera engi emaki - suddenly meets in person the man she had heretofore only known in the world of dreams. The aforementioned Shinran sho'nin eden, in depicting the death of Shinran, includes a sliding door upon which can be seen the painting of a sandy seashore. No doubt, the sandy banks of a wave-beaten seashore were rich with poignant connotations.

It is not easy to trace the origin of this image of sandy seashore, known as subama. The Isle of Penglai 蓬莱 (J: Hōraitō), that idyllic island-home of the blessed immortals believed to be located somewhere east of Parhae, was a prominent topos in Sinitic literature. In Japan, the Isle of Penglai came to symbolize an otherworldly place somewhere far out to sea, associated, among other things, with Mount Fudaraku 補陀落山 (Skt: Potalaka), temporary dwelling place of the bodhisattva Kannon while on earth, such that the seashore itself served as a symbol of the sacred and the otherworldly. The "Jigoku gokurakuzu byōbu" 地 獄極楽図厥風, a folding screen produced sometime during the thirteenth and fourteenth century, (Konkai kōmyōji Temple 金戒光明寺), in Kyoto, depicts scenes both of the Buddhist purgatory and of the Pure Land. In this depiction, the Pure Land towers atop a sandy seashore somewhere far over the sea. Here, too, the seashore represents a sacred space. Even more interesting is the fact that

\footnotetext{
${ }^{9}$ For research on the three "Hamamatsuzu byōbu" screens, see Tanaka Ichimatsu 田中一松, “Hamamatsuzu byōbu” 浜松図屏風, Kokkea, 738, September 1953; Mochimaru Kazuo, "Hamamatsuzu byōbu ni tsuite” 浜松図屏風について, Bijutsu kenkyyu, 177, September 1954; Mizuo Hiroshi 水尾博, “Hamamatsuzu byōbu” 浜松図屏風, Kokka, 806, April 1959; Izumi Mari, Chüsei byōbue kenkyyü中世屏風絵研究. Tokyo: Chūō Kōron Bijutsu Shuppan, 2013; Izumi Mari, "Hamamatsuzu byōbu (held by the Ministry of Culture): Umibe no Shikie” 浜松図屏風 (文化庁蔵): 海 辺の四季絵, Kokka, 1432, February 2015.
} 
this folding screen was produced expressly for use in the Buddhist service conducted for those who were about to breath their last. Upon the reverse side of this same screen may be seen a painting of Amida 阿弥陀 (Skt: Amitābha), the Buddha who welcomed the departed souls of the faithful into paradise. Marks around his hand where five-colored strings were once attached-strings representing karmic bonds, which believers would grip in the final throes of deathcan still be discerned. This folding screen served as a powerful medium for guiding newly departed souls into the Pure Land. ${ }^{10}$

Folding screens were not the only medium through which this image of the sacred seashore was artistically depicted. Miniature models, known as tsukurimono $\supset く り$ 物, literally, "fabricated objects," were constructed, often as a means of representing the Isle of Penglai, replete with tiny flowers, birds, and sometimes people. The earliest recorded use of such miniature models occurs in relation to the grand eye-opening (kaigen 開眼) ceremony—roughly similar to the modern-day unveiling ceremony of a monumental sculpture- conducted in the fourth month of the fourth year of Tenpyō shōhō 天平勝宝 (752) in celebration of the completion of the Great Buddha at Tōdaiji Temple 東大寺. The Shōsōin Treasury 正倉院 at that same temple contains two miniature representations of scene, one known as the Lotus Pond (Renchi 蓮池), the other as the Ephemeral Mountain (Kazan), which might very well represent the sort of models employed during the eye-opening ceremony of $752 .{ }^{11}$ Waves beating against the seashore, constantly in motion, forever taking on new shapes, have, since ancient antiquity, been invested with a sense of the sacred. The following poem is a fine example of this: “The waves coming in at Shiga Bay (Shiga no ura 志賀の浦) glisten with an array of five colors - a reminder of that ancient age when [the deity of Miwa 三輪] descended from the heavens and strode across shore."12 Another telling poem reveals the close relationship between waves along the seashore, on the one hand, and pine trees and birds, on the other: "Countless birds floating upon the water's evening waves cry out as the wind signs its lonesome tune through pine trees along Shiga Bay." 13 The seashore, waves, flowers and treespine trees especially — were all understood as being somehow sacred, or symbols

\footnotetext{
${ }^{10}$ Kasuya Makoto 加須屋誠, Bukkeyō setsuwaga no kinō: shigan to bigan no ikonorojż 仏教説話画の機 能一此岸と彼岸のイコノロジー. Tokyo: Chūō Kōron Bijutsu Shuppan, 2003.

${ }^{11}$ For research pertaining to these miniature models of the seashore, see Inagi Nobuko 稲城 信子, “Tsukurimono no keifu: suhama, yamagata, shimeyama” 造物の系譜一洲浜・山形・標山 など, Gangōji bunkazai kenkyüjo nenpō, 1977-1978, March 1979; Koizumi Masako 小泉賢子, “Suhama ni tsuite” 洲浜について, Bijutsushi kenkyū, 33, November 1995; Sano Midori 佐野みど り, Füryü, zōkei, monogatari: Nibon bijutsu no kōooo to yōtai 風流・造形・物語: 日本美術の構造と様態. Tokyo: Sukaidoa, 1997.

${ }^{12}$ Shügyokushū 拾玉集, poem no. 1484. Hirata Hideo 平田英夫, “Seinaru nami no denshō: chūsei jingika no 'sasanami' wo megutte” 聖なる波の伝承一中世神祇歌の『ささ波』をめぐっ て-, Chüsei bungaku, 47, June 2002.

${ }^{13}$ Horikawa byakushu 堀川百首, poem no. 977.
} 
of the sacred. Miniature models, likely similar to those described above, were created and displayed during poetry matches. While this is not the place for a detailed examination of these models, suffice it to say these contained representations of pine trees, bamboo, cranes, and various flowers and trees, and were, along with folding screens likewise containing paintings of pine trees growing along a wave-beaten shore, an integral part of the elaborate performances witnessed at these poetry matches.

\section{Folding Screens and Performance Venues: From Temporary Furnish- ings to Permanent Fixtures}

\section{a. Furnishings for Ritual Spaces}

Let us return to the entry in Kanmon nikki dealing with the Tanabata Ritual. The two folding screens displayed during that event were, as previously noted, not merely decorative furnishings, but partitions, endowed as they were with highly-refined, reflective gold pigment, along with auspicious representations of the sea, boats, and pine trees, capable of delineating a unique space in which the banquet could be held. Rituals and public banquets, however, were not the only venues in which folding screens were employed in order to temporarily demarcate specially designated spaces. Folding screens were also used in a variety of ways within the private home, where they also served as markers or dividers of space. It is necessary, when examining the uses of folding screens within private homes, to distinguish between those folding screens intended for purely practical, daily use-merely as temporary partitions — on the one hand, and those intended for some special purpose, on the other. One way of doing this is to pay attention to the decorative properties of a given screen, namely, its materiality and its iconography, and to what sorts of pigments and materials are used, and the types of images and motifs painted upon its surface. We must also take into consideration the manner or orientation in which a given folding screen was placed. During inauspicious occasions, for example, a folding screen normally employed for daily use would be turned upside down as a means of temporarily symbolizing the transformation of otherwise mundane space into something out of the ordinary. ${ }^{14}$

Aside from their use in temporarily delineating sacred or pure spaces during such special events as childbirth, funerals, and Buddhist services, I would argue that folding screens were used, moreover, during the Muromachi period, as a means of demarcating or encircling performative venues. Performances of the tea ceremony, poetry matches, and $N o$ plays all necessitated the temporary delineation of a special space in which actors and audiences could appreciate these events. There has been little, if any, research done into the precise manner in

\footnotetext{
${ }^{14}$ Suzuki Hiroyuki 鈴木廣之, “Kaiga no arukeorojī: Muromachi jidai ni okeru byōbue no igi”" 絵画のアルケオロジー一室町時代における屏風絵の意義, Kokka, 1200, November 1995.
} 
which folding screens were positioned around these venues. Kanmon nikeki informs us that, upon the performance of a tea ceremony, a poetry match, or a bout of linked poetry, the sliding doors were removed and replaced with folding screens, which were arranged in such a way so as to encircle the entire venue. The Inryoken nichiroku tells us that gold-ground folding screens were arranged around the venue of a poetry match in which Sinitic verses were presented. ${ }^{15}$ Regardless of the particular event, these folding screens were, as a rule, removed and stored away after the event had been concluded.

The practice of arranging folding screens around a given venue seems to have waned during the Momoyama period, that is, the last two decades of the fifteenth century, when a new form of residential architecture known as shoinzukuri 書院造 (study or drawing room layout) came into fashion. The demarcation of separate rooms within the house was then, as now, executed by means of permanent walls, while sliding doors, decorated with painted images and fitted into these walls, could be opened or closed to either enlarge or limit the size of a room when so desired. One question begs to be asked: how did the traditions governing the proper furnishing of special venues, detailed in contemporary sources such as Kanmon nikkei, transform as tea rooms (chashitsu 茶室) and $N o$ 能 stages became permanent and highly specialized fixtures? The following examination of folding screens and images of the seashore used in tea ceremony and other performative venues, while not strictly of indoor furnishings, nevertheless offers a glimpse into at least the vestiges of earlier Muromachi-period practices of indoor furnishings, when folding screens still played a central role in the demarcation of space.

\section{b. Concepts of the Seashore as Seen in the Tea Ceremony}

The space designated for a performance of the tea ceremony was originally referred to as a kakoi 囲い, that is, an encircled space: before the development of specialized tea rooms, the tea ceremony was customarily carried out in the corner of a larger room. Sötan nikki 宗湛日記 (The Diary of Sötan, 1586-1613) includes an entry for the fifth day of the fifth month in the second year of Keichō 慶長 (1597), wherein we are told of a tea ceremony performed by the seashore, with participants encircled by a gold-ground folding screen. Here, instead of bringing the seashore to the tea performance in the form of a painting or model, as was customary, we see the performers bringing their tea to the seashore. This particular tea ceremony was of special significance: an assembly of daimyo was temporarily camped along the seashore of Hakata, where they were rallying troops in preparation for a large-scale invasion of Korea. The tea ceremony was held at Iki no matsubara 生松原, literally, the plain of living (or life-giving) pines,

\footnotetext{
${ }^{15}$ Akazawa Eiji 赤澤英二, “Jūgo seiki ni okeru kinbyōbu ni tsuite”十五世紀における金屏風に ついて, in Takeda Tsuneo 武田恒夫 and Yamane Yūzō 山根有三, ed., Nihon byōbue shüsei 日本屏 風絵集成, volume 6. Tokyo: Kōdansha, 1978.
} 
a coastal region in Hakata. The venue for this tea ceremony was delineated by a single gold-ground folding screen. The iron tea kettle was hung from the lower branch of a pine tree, while the charcoal for boiling water was heated directly upon the sandy seashore. After the development of specialized, permanent tea rooms, the inner space of the tea ceremony was reached through a low-framed door cut into the wall expressly for that purpose. Once in the room, one was effectively cut off from the everyday world outside. Once settled in the quiet of the tea room, one would, upon hearing the soft bubbling of boiling water in the kettle, call to mind the rustling of wind through pine trees. ${ }^{16}$ Some tea ceremonies would adopt the use of painted images of waves and so-called matsushima (pine island) tea jar in order to further enhance the atmosphere. ${ }^{17}$ In other words, the seashore, being as it was a symbol of otherworldliness, of something wholly out of the ordinary, was incorporated into the interior space of the tea room by means of various artistic innovations.

This tea ceremony detailed in Sötan nikki, what with its stalwart daimyo and their soldiers setting up a gold-ground folding screen by the roaring seashore, anticipating the imminent invasion of Korea, may seem contrary to modern conceptions of the tea ceremony, which is now seen as a sublimely peaceful event. It must be understood, however, that during the Muromachi period, tea ceremonies served an important political function, providing those in power with a congenial venue in which to congregate and reconfirm their mutual alliances. That these daimyo chose to hold their tea ceremony close by the seashore, that they chose, moreover, to encircle themselves with a gold-gilt folding screen, is proof that they saw this event as something fundamentally separate from everyday life. The idea of a tearoom that was wholly outside the realm of daily life was, at least conceptually, already in the making. It was this very concept that inspired the architects of Nishi Honganji Temple to construct a tearoom-the Hiunkaku, or soaring-cloud pavilion—along the shore of a pond.

\section{c. Performance Venues}

Let us now turn our attention to the performative spaces of $N \bar{o}$ drama. Prior to the development of specialized, permanent stages for the performance of $N^{\bar{o}}$ plays, performances were held on temporary stages erected in temples and shrines, or along the riverside. Sixteenth-century illustrations reveal a transitionary period between temporary and permanent stages for $N o$ performances. The “Rakuchū rakugaizu" screen 洛中洛外図 (Scenes Inside and Outside the Capital) in the collection of at the National Museum of Japanese History (Kō Version, c. 1525) depicts a temporary stage composed of boards surrounded by a sort of enclosure, signifying the special nature of this space. The "Kannōzu byōbu" 観 能図屏風 (painted sometime after 1607), which vividly depicts a Nö performance

\footnotetext{
${ }^{16}$ Yamanoue söjiki 山上宗二記.

${ }^{17}$ Matsuya kaiki 松屋会記, Tenbun 天文 11 (1542) April 3.
} 
held in 1588, shows us a gold-ground folding screen behind the stage upon which is painted waves, birds, and reeds. The "Sōōji byōbu” 相応寺㞔風 (Sōōji Temple Folding Screen, seventeenth century) likewise contains an image of a folding screen upon which can clearly be seen paintings of flowers and trees. The permanent backdrops of modern-day $N \bar{o}$ stages are routinely decorated with paintings of pine trees. Before the Edo period, however, folding screens served in place of permanent backdrops, and sported images not only of pine trees but of various other trees, as well. The practice of painting exclusively pine trees was, in all probability, not established until the development of permanent No stages during the Momoyama period. ${ }^{18}$ Also of interest here is the presence, during that period when temporary stages were still in use, of folding screens behind the audience as well. The “Hōkoku saireizu byōbu” 豊国祭礼図屏風 (early seventeenth century), which depicts a grand memorial ceremony held in 1604, shows a gold-ground folding screen behind the audience decorated with an image of a pine tree.

Incidentally, this juxtaposition of motifs depicted on the above screens brings to mind the interior design at Azuchi Castle 安土城, completed in 1579. According to Shinchō kōki 信長公記 (Public Records of Nobunaga, 1568-1582), the artist Kanō Eitoku 狩野永徳 (1543-1590) was commissioned to provide all the wall paintings for the castle. This same source tells us that the fifth floor of the central tower contained a reception hall consisting of three distinct areas: the main and most spacious area, the walls of which were decorated with paintings of pine trees, and two smaller areas, one to the West and one to the South of the main area, their walls likewise decorated, respectively, with images of rocks and bamboo. These three rooms were referred to as the Pine Room, the Rock Room, and the Bamboo Room. When No performances were held in the main pine room, the audience was seated in the Rock room, while the musicians and chorus singers were seated in the Bamboo Room This last room was likely used also as a changing room (kagaminoma) where performers would don their masks, thereby transforming themselves into something divine. ${ }^{19}$ Instead of folding screens, this reception area uses permanent wall paintings to represent the same images we saw earlier, namely, pine trees, rocks (to represent the seashore), and bamboo. Here, the sacred seashore has moved from temporary folding screens to permanent walls.

Nishi Honganji Temple contains the oldest extant permanent $N \bar{o}$ stage: the Kita Nō butai 北能舞台, or Northern Nō stage. Aside from this, however, the temple also contains a Minami Nō butai 南能舞台, or Southern Nō stage. When

\footnotetext{
${ }^{18}$ Ido Misato, "Matsu no e to nōbutai wo meguru ichi kōsatsu: unkokuha kanren no shiryō wo chūshin ni shite” 松の絵と能舞台をめぐる一考察一雲谷派関連の資料を中心にして一, Nōgaku gakkai, ed., Nō to kyōgen, 7, April 2009.

${ }^{19}$ Miyagami Shigetaka 宮上茂隆, “Azuchijō fukugen” 安土城復元, in Nihon bijutsu zenshū 日本 美術全集, volume14, Tokyo: Kōdansha, 1992.
} 
plays were performed upon the Southern stage, the audience was seated in a large reception area, the walls of which were decorated with large paintings of pine trees. Just below the tatami mats of this room was another indoor Nō stage, allowing for performances to be held within the hall itself. In addition to that, a room known as the Nami no ma 波の間 or Room of Waves was set aside at the foot of the bridge-like passage (hashigakari 橋掛かり) leading onto the southern Nò stage. This space, where performers supposedly waited before entering the stage, was so called because it was decorated with paintings of waves. Performers would pass by this room of waves on their way across the aforementioned bridge, ultimately arriving on an expansive stage covered completely with fine white sand. Add to this the painted pine decorating the audience's seating area, and we can see how this entire permanent performance space had been transformed into a figurative seashore. It is not certain when exactly this symbolic framework was thoroughly incorporated into those performance spaces dedicated exclusively to $N_{o}$ theater. That this framework has since become a mainstay is evinced by the fact that modern-day indoor Nō stages incorporating backdrops including painted pines trees, are surrounded on three sides by shallow channels full of white pebbles or sand, and have three pine trees placed along the bridge-like passage that leads on and off the stage.

Ogasawara Kyōko informs us that, during the Muromachi period, performances of such dance arts as dengak $u$ 田楽 and sarugaku $u$ 猿楽 tended to be held outside of the city at temples or shrines, along the riverside, or at the crossroads. All of these venues were intimately associated, in one way or another, with the realm of the dead. ${ }^{20}$ Amino Yoshihiko also tells us that woods, fields, and mountains once served as asylums, and that seashores once served as both burial and ritual grounds. These liminal spaces, he argues, were the original birthplaces of premodern performing arts. ${ }^{21}$ If the origins of dengaku and No theater are indeed to be traced back to such liminal spaces, it is no wonder that images reminiscent of the seashore-one of the most poignantly liminal of earthly spaces-were incorporated into the permanent $N_{o}$ stages of later ages, where they could in turn endow these stages with an air of the otherworldly. In the genre of No plays known as dream or phantasmagoric drama (mugennō 夢幻能) in particular, where the protagonist is inevitably a visitor from another world, most often from the realm of the dead, symbolic seashore imagery played a crucial role in creating the extra-mundane atmosphere appropriate for such performances.

\footnotetext{
${ }^{20}$ Ogasawara Kyōko 小笠原恭子, “Chūsei kyōraku ni okeru kanjin kōgyō: muromachi ki” 中世 京洛における勧進興行一室町期, Bungaku, 48:9, September 1980.

${ }^{21}$ Amino Yoshihiko 網野善彦, Nihonron no shiza: rettō no shakai to kok:ka 日本論の視座一列島の 社会と国家. Tokyo: Shōgakukan, 1993.
} 


\section{Conclusion}

This article began with a reconsideration of an entry in the Kanmon nikki dealing with Yamato-style folding screens. Having shown how the folding screens employed during the Tanabata Festival were gold-ground screens decorated with paintings of pine trees and the seashore, I then indicated the importance of the materiality of shimmering pigments, such as gold, silver, and mica, as well as iconography, as factors contributing to the ability of folding screens to delineate sacred or purified space. In this capacity, folding screens could serve as temporary partitions, employed as indoor furnishings on special occasions, thereby creating extra-mundane spaces as necessity demanded. The development, within the realm of residential architecture, of more permanent dividers of spacewalls and sliding doors-brought about a decline in the use of folding screens. Instead, as in the case of Azuchi Castle and Nishi Honganji Temple, adjacent rooms were decorated with wall paintings, assigning each room or area a unique and permanent function. Despite artistic changes concomitant with the transition from folding screens to painted walls, the result of which was the establishment of wholly distinct tearooms and Nò stages, the iconography of seaside pine (bamamatsuzu) remained unchanged, insofar as these symbols continued to endow performative venues with a sense of the sacred and the otherworldly. To conclude, folding screens, whether directly or somewhat indirectly-as in the case of the term kakoi (encircled area) used to designate the space in which a tea ceremony was performed - with their consistent iconography of the seashore, served to recreate those liminal spaces in which the arts were, in more distant times, first developed and practiced. 


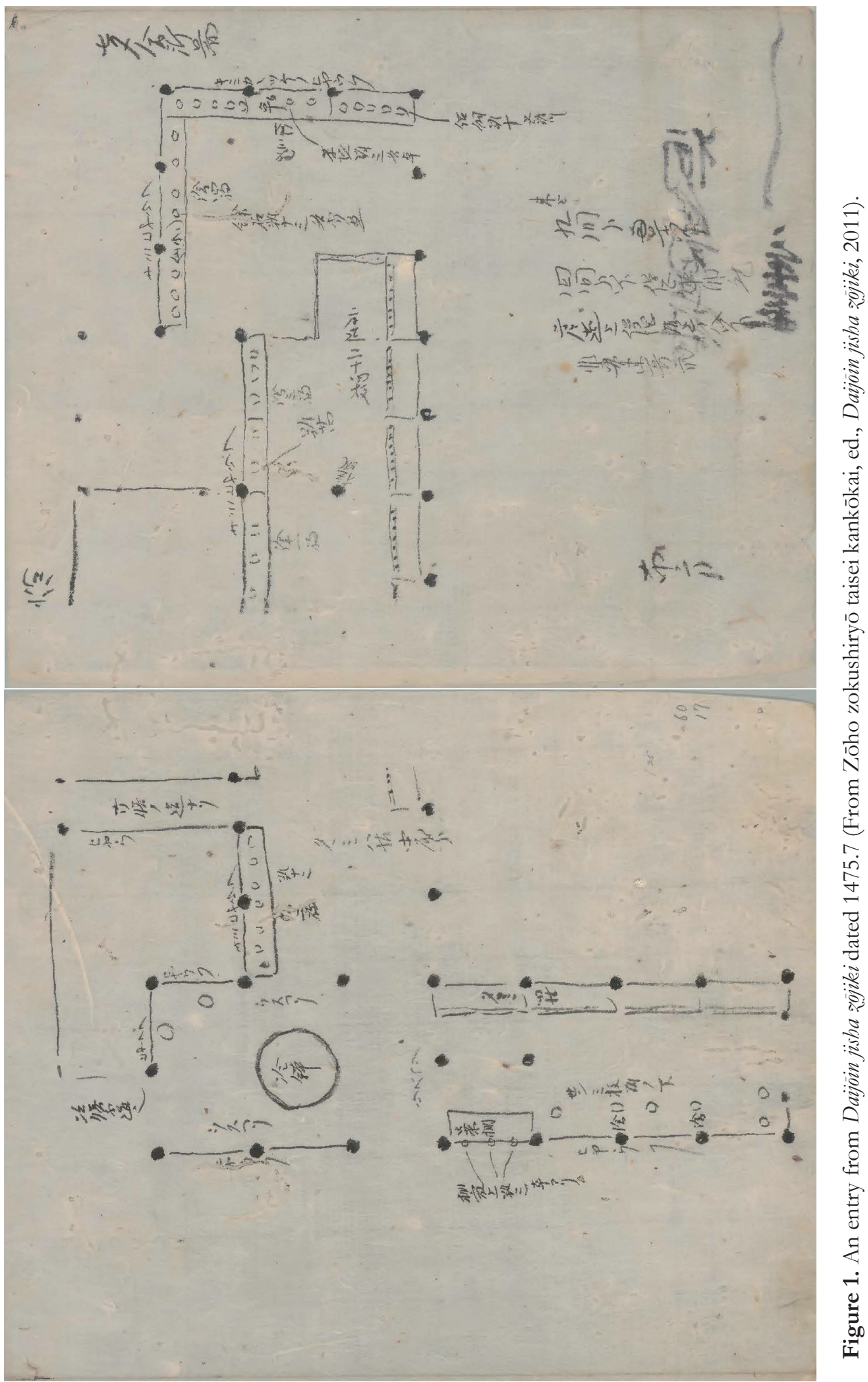


The Space and Liminality of Folding Screens
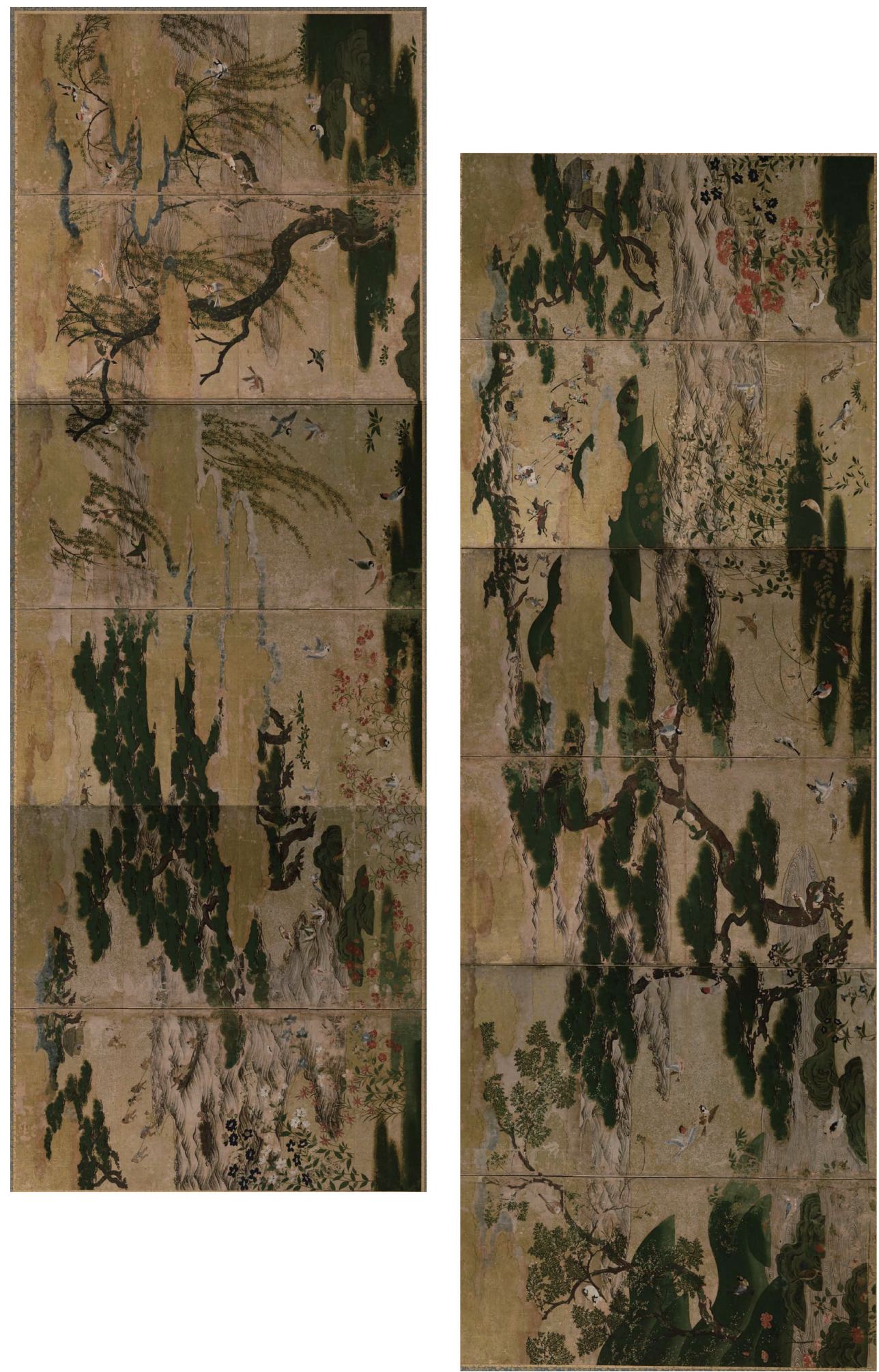

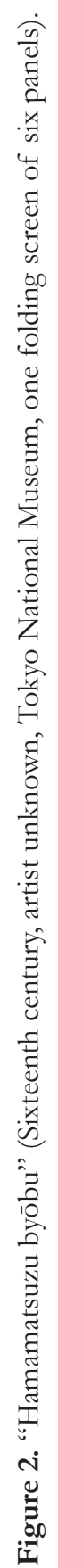

